\title{
Migration and asylum law of the V4 in the European Union context: between harmonisation and reluctance
}

\author{
ÁGOSTON MOHAY
}

\section{Sciendo}

Politics in Central Europe (ISSN: 1801-3422)

Vol. 17, No. 15

DOI: 10.2478/pce-2021-0031

\begin{abstract}
Ever since the 2015 migration and asylum crisis, the legal regulation of this field in the European Union has been debated strongly in almost all its aspects. The member countries of the Visegrád Group (V4) have voiced dissent regarding a number of EU measures in this field, leading to political and legal confrontation. After a brief review of the public law context of EU migration and asylum policy and the general attitude of the V4 towards these regulatory fields, this paper elaborates how the EU and the V4 reacted - in legal terms - to the 2015 migration and asylum crisis and to each other's measures, focusing on three key V4 policy goals. The paper also analyses the reception of the 2020 proposal on the New Pact on Migration and Asylum and discusses whether it can be seen as the way forward in terms of a more consensual policy approach. The paper finds that although the approach of the V4 has had a perceivable effect on that of the EU, elements of disagreement remain; it further argues that the harmonious elements of the approaches of the EU and the V4 could potentially be built upon to reach a compromise, but maintains that policy-based reluctance cannot have an effect on obligations laid down by EU law.
\end{abstract}

Keywords: migration and asylum law, European Union, Visegrád Group, New Pact on Migration and Asylum

\section{Introduction}

Ever since the 2015 European migration and refugee crisis, the regulation of migration and asylum in the European Union has been a seriously contentious issue in almost all its aspects. Migration and asylum policy are competences 
that are shared between the EU and its Member States, which results in two levels of regulation, and which allows Member States some regulatory freedom. The Visegrád Countries (V4), i.e. Czechia, Hungary, Poland and Slovakia, have often been among those EU member states which have voiced dissent to some EU initiatives in this field, leading to political and legal disputes.

This paper first provides an overview of the legal context of EU migration and asylum policy, with brief reference to the general policy attitude of the V4 towards these regulatory fields (Part 1). This is followed by an elaboration of how the EU and the V4 reacted - in legal terms - to the 2015 migration and asylum crisis and to each other's measures, divided into three policy elements (Part 2). The paper then analyses the V4 reception of the 2020 proposals under the New EU Pact on Migration and Asylum and discusses whether it can be seen as the way forward in terms of a more consensual policy approach (Part 3). Finally, the paper offers concluding remarks, arguing that even though the approach of the V4 has had a perceivable effect on that of the EU, leading to a more nuanced concept of solidarity, elements of disagreement remain; it further argues that the harmonious elements of the EU and V4 approaches could potentially be built upon to reach a compromise, but also maintains that policy-based reluctance cannot have an effect on obligations laid down by EU law (Part 4).

\section{Setting the scene: the aims and tools of EU migration and asylum law - and the position of the V4}

The European Union is a supranational entity based on law - the relevance of law as an essential tool of European integration cannot be overemphasised. Of course, this is not to say that political strategies and interests do not play a role at the European Union level, but that the EU is not only a community founded on the rule of law, ${ }^{1}$ but one that is intrinsically linked to law in its functioning, as the latter serves as the main instrument of integration: unlike to 'traditional' international organisations, the EU has been endowed with legislative competences by its member states, and this transfer of sovereignty allows it to adopt binding laws in ways which one could say are more similar to national legislative systems than to traditional international law-making.

'Integration through law' is how the EU realises its goals in its various policies, including migration policy. ${ }^{2}$ Thus, to be able to analyse the situation of the $\mathrm{V} 4$ in recent EU migration and asylum policy, we need to be clear about the relevant EU legal framework.

1 This was expressly stated by the Court of Justice of the EU in its judgment in C-294/83 Les Verts v. Parliament (EU:C:1986:166), para. 23.

2 On the notion of integration through law in Europe in general, see Cappelletti et al 1986. 
Immigration and asylum regulation are part of the EU's justice and home affairs policy, officially called the Area of Freedom, Security and Justice (AFSJ) as defined by Art. 3(2) of the Treaty on European Union (TEU). The EU's immigration and asylum law applies only to third-country nationals (TCNs), i.e. individuals who are not EU citizens. ${ }^{3}$

According to the Treaty on the functioning of the European Union (TFEU), the AFSJ is a competence shared between the EU and the Member States (Art. 4). This means that the EU and the Member States may both legislate and adopt legally binding acts in a given competence area, but the Member States may only exercise their competence to the extent that the EU has not exercised its competence (Art. 2 TFEU). In reality, EU and Member State constitutional practice show that the aforementioned delimitation does not necessarily mean that the member states cannot adopt any binding regulations in fields where any EU law exists: on the other hand, these two levels of regulation often coexist - though any exercise of the EU's competence definitely 'outlaws' any contradictory national legal acts (Schütze 2015: 85-86).

The EU competences in the field of immigration law are specifically enumerated in Article 79 TFEU. Accordingly, the EU's common immigration policy is set up in order to ensure the efficient management of migration flows, the fair treatment of TCNs residing legally in the EU Member States (i.e. legal immigrants), and the prevention and combating of illegal immigration and trafficking in human beings. Migration law measures are adopted according to the ordinary legislative procedure, where the initiative is presented by the European Commission, and decided upon by the European Parliament (EP) and the Council on an equal footing (Article 289 TFEU). Measures to provide incentives and support for the action of Member States regarding the integration of legal migrants can also be adopted in a similar way. ${ }^{4}$

The effective managing of the EU's returns policy ${ }^{5}$ pertaining to immigrants who are illegally in the territory of one of the EU Member States necessarily requires regulated cooperation with third countries. The EU - as a subject of

3 What follows below is a brief summary of the main elements of this EU policy field which are most relevant for the arguments of this paper. For a broader general discussion of EU migration and asylum law see e. g. Gyeney - Molnár 2016: 183-249.

4 Nota bene: It is important to point out that the aforementioned legal bases do not affect the right of Member States to determine volumes of admission of third-country nationals coming from third countries to their territory in order to seek - employed or self-employed - work (Article 78, para. 5.). The EU thus does not have any power to oblige the Member States to provide access to their labour markets in an unlimited fashion.

5 The basis of the returns policy is Directive 2008/115/EC of the European Parliament and of the Council on common standards and procedures in Member States for returning illegally staying third-country nationals (OJ $2008 \mathrm{~L} 348$ ). In the context of the Directive, 'return' covers both voluntary departure in compliance with an obligation to return, as well as enforced return (removal). (See the definitions under Article 3 of the Directive). 
international law - can conclude readmission agreements with such states. ${ }^{6}$ Under customary international law, states do have an obligation to readmit their own nationals; such an obligation does not exist regarding non-nationals, thus underlining the need for such agreements (Cassarino 2010: 13). This is an important part of the external dimension of EU migration law.

The central aim of the EU relating to asylum (Article 78 TFEU) is to develop a common European asylum policy, ensuring the principle of non-refoulement. ${ }^{7}$ To this end, the EU has adopted legal acts concerning a uniform status of asylum and subsidiary protection for $\mathrm{TCNs}^{8}$; common procedural rules for granting international protection ${ }^{9}$; rules to decide which EU Member State is responsible for processing an asylum application ${ }^{10}$ as well as common standards regarding reception conditions for applicants for international protection ${ }^{11}$. The most controversial piece of secondary legislation that has been adopted in this policy is the Dublin Regulation, which concerns rules on the responsibility to process a given asylum application. ${ }^{12}$ Cooperation with third countries is also envisaged by the treaty, as well a common system of temporary protection for displaced persons in the event of a massive inflow. Article 78(3) further provides a legal basis for the adoption of provisional measures in the event of one or more Member States being faced with an emergency situation entailing a sudden inflow of TCNs. Such measures can be adopted not via the ordinary legislative procedure, but via a different and specific procedure: the Council can adopt such measures on a proposal from the Commission and after consulting the EP.

Migration and asylum law are organically linked to the EU law and policy of border controls and visas (Article 77 TFEU). The key legal acts to be pointed

6 Until the time of writing, the EU has concluded 18 readmission agreements: https://ec.europa.eu/home-affairs/what-we-do/policies/irregular-migration-return-policy/return-readmission_en. For context and evaluation see De Bruycker et al 2019: 131-144.

7 The EU asylum policy is required by the same provision of the TFEU to be in accordance with the Geneva Convention of 1951 relating to the status of refugees and its 1967 Protocol.

8 Directive 2011/95/EU of the European Parliament and of the Council of 13 December 2011 on standards for the qualification of third-country nationals or stateless persons as beneficiaries of international protection, for a uniform status for refugees or for persons eligible for subsidiary protection, and for the content of the protection granted (OJ $2011 \mathrm{~L} 337$ ).

9 Directive 2013/32/EU of the European Parliament and of the Council of 26 June 2013 on common procedures for granting and withdrawing international protection (OJ $2011 \mathrm{~L} 180$ ).

10 Regulation (EU) No 604/2013 of the European Parliament and of the Council of 26 June 2013 establishing the criteria and mechanisms for determining the Member State responsible for examining an application for international protection lodged in one of the Member States by a third-country national or a stateless person (OJ $2013 \mathrm{~L} 180$ ).

11 Directive 2013/33/EU of the European Parliament and of the Council of 26 June 2013 laying down standards for the reception of applicants for international protection (OJ $2013 \mathrm{~L} \mathrm{180)}$.

12 Regulation (EU) No 604/2013 of the European Parliament and of the Council of 26 June 2013 establishing the criteria and mechanisms for determining the Member State responsible for examining an application for international protection lodged in one of the Member States by a third-country national or a stateless person (OJ 2013 L 180). 
out are the Schengen Borders Code ${ }^{13}$ and the Regulation on FRONTEX, the EU's border protection agency. ${ }^{14}$ The EU also has a visa regulation, determining from which state a visa is required to enter the $\mathrm{EU}^{15}$ as well as a Visa Code. ${ }^{16}$

Within this context, what can be said about the initial attitude of the V4 countries to migration? Since the regime changes in the region, the V4 countries have been less confronted with immigration as a whole, and especially with migration from outside the area of Central Europe, as most immigrants and asylum seekers arrived from the wider region; the very first - temporary 'shock' of mass immigration was the result of the Yugoslav wars in the 1990s (Kováts 2016: 351-353). Among other things, this contributed to the V4 listing migration and border control issues among the seven key areas relevant for cooperation among them at the Bratislava Summit in 1999 (Remek 2015: 289). These issues, however, remained of rather secondary political importance in and around the time the V4 acceded to the European Union in 2004.

From among the V4, Czechia does not have any land external borders (i.e. all of its bordering states are EU Member States). Hungary, Poland and Slovakia, on the other hand, do have non-EU neighbours. All of the V4 states are members of the Schengen Area, the rules of which have fully applied to them since December 2007. ${ }^{17}$ The V4 have not attempted to obtain a general opt-out from any elements of the AFSJ under primary EU law, ${ }^{18}$ though some limited and specific opt-outs based on secondary EU law are in place - in the latter sense, Hungary and Poland have made use of the opt-out possibility provided for by the Returns Directive. ${ }^{19}$

13 Regulation (EU) 2016/399 of the European Parliament and of the Council on a Union Code on the rules governing the movement of persons across borders (OJ $2016 \mathrm{~L} 77$ ).

14 Regulation (EU) 2019/1896 of the European Parliament and of the Council of 13 November 2019 on the European Border and Coast Guard and repealing Regulations (EU) No 1052/2013 and (EU) 2016/1624 (OJ 2019 L 295).

15 Regulation (EU) 2018/1806 of the European Parliament and of the Council of 14 November 2018 listing the third countries whose nationals must be in possession of visas when crossing the external borders and those whose nationals are exempt from that requirement (OJ $2018 \mathrm{~L} 303)$.

16 Regulation (EC) No 810/2009 of the European Parliament and of the Council of 13 July 2009 establishing a Community Code on Visas (OJ 2009 L 243).

17 See Council Decision 2007/801/EC of 6 December 2007 on the full application of the provisions of the Schengen acquis in the Czech Republic, the Republic of Estonia, the Republic of Latvia, the Republic of Lithuania, the Republic of Hungary, the Republic of Malta, the Republic of Poland, the Republic of Slovenia and the Slovak Republic (OJ 2007 L 323)

18 Opt-outs in this context mean treaty-based possibilities for certain EU Member States to refrain from taking part in certain elements of a particular policy field. In the AFSJ, such special rules currently apply - following Brexit - only to Ireland and Denmark, albeit with differences (Monar 2010: 279-281).

19 Article 2(2) of said Directive allows Member States to not apply the Returns Directive to several of its provisions to persons apprehended or intercepted by the competent authorities in connection with their irregular border crossing at the external border. In fact, most EU Member States with external EU land borders have made use of this option, though they nevertheless remain bound by the Directive's most crucial safeguards in accordance with its Article 4(4). (See European Union Agency for Fundamental Rights 2020: 8.) 
The 2015 migration and asylum crisis - regardless of whether we interpret it as a single crisis or multiple overlapping crises (Pachocka 2016:102-103) - put migration very much into the spotlight both in political and legal terms in the European Union as a whole, and also in the V4 states..$^{20}$

\section{Coming to blows: EU and V4 responses to the migration and asylum crisis}

The migration and asylum crisis of 2015 saw unprecedented numbers of registered illegal border crossings and applications for asylum in the EU. It is not the task of this paper to analyse the crisis itself, it is enough here to state that the crisis affected the Member States unevenly: one possible differentiation between them distinguishes between "frontline" or "first reception" states (e.g. Italy), transit countries (e. g. Hungary), target countries (e.g. Germany) and states not directly affected, including Slovakia and Poland, both members of the V4 (Pachocka 2016: 104). In terms of numbers, Hungary was definitely most seriously affected by the events from among the V4. This can be illustrated by the percentage share of the V4 of all asylum applications submitted in the EU in 2015: Hungary received $13.4 \%$ of the applications, Poland $1.3 \%$, whereas the share of Czechia and Slovakia remained marginal, between 0.3-0.1\% (Pachocka 2016: 106).

The V4 made various joint statements in 2015 and 2016, outlining their views on migration and asylum policy and how the EU should react to the crisis. These policy statements strongly emphasised at least three common points: (1) the importance of safeguarding the external borders and fulfilling related EU-obligations including the Schengen acquis; (2) refusing the so-called 'open door' policy spearheaded by Germany at the time; and (3) the effective management of the root causes of migration flows, i.e. addressing the push factors of migration, assisting the countries of origin and thereby reducing migration towards the EU (Szalai et al 2017: 20-21). It would be an oversimplification to paint a picture of full and unconditional unity among the V4 in the field of migration, as coherent and incoherent features can both be identified (Bauerová 2018a: 100-102). The three elements mentioned above nevertheless serve as adequate focal points for analysing the response of the V4 in more detail. It would go beyond the remit of a single paper to outline all of the EU measures and the V4's responses in the context of the crisis. The following sections will thus

20 It would exceed the dimensions of this paper to provide a comprehensive account of the migration policy of the V4 from the regime change to the present day. For such an overview (in Hungarian) see Stepper 2018: 55-97. 
analyse these aspects through the lens of the three policy priorities described above $^{21}$ - from a legal perspective. ${ }^{22}$

\section{General considerations}

The starting point for the EU's measures - in legal terms - are the existing Treaty rules and secondary legal acts, as well as the 2015 Agenda on Migration. The 2015 Agenda, itself not a legal act, contained a number of short- to mid-term initiatives by the European Commission to address the crisis, which were later partly turned into legal acts. ${ }^{23}$

As Member States of the EU, the V4 are obliged to comply with the EU measures adopted in this field - an obligation most generally articulated by the principle of sincere cooperation (also known as the loyalty clause), according to which Member States are required to take any appropriate measure, general or particular, to ensure fulfilment of the obligations arising out of primary or secondary EU law, as well as to facilitate the achievement of the EU's tasks and refrain from any measure which could jeopardise the attainment of the EU's objectives (Article 4 Para. 3 TEU). This does not prevent infringements of EU law, of course, a number of which will be described below. In essence, most of the legal tensions between EU law and national (V4) law stem from the shared nature of the legislative competences in the field of migration and asylum. At the policy level, the V4 made it clear in their first joint reaction to the 2015 Agenda that they had a number of reservations to some of its suggested initiatives, emphasising the need for an effective returns policy and arguing that any relocation scheme needed to rely on voluntary participation. ${ }^{24}$ Whereas this standpoint would influence negotiations in the European Council and the Council, the political reception of the Agenda has of course no effect on the legally binding nature of the already existing EU legal acts in this policy area.

In a political sense, the V4 and notably Hungary have been vocally critical of the EU's response, calling it cumbersome, slow and overly generous in facilitating entry into the EU (Pap et al 2019: 60).

21 This delimitation of focus also means that some aspects will not be analysed, including the notion of the criminalization of migration (sometimes termed 'crimmigration'). On this issue see Hautzinger 2019: 149-172.

22 For more of a policy- and politics-oriented analysis, see Glied - Zamęcki 2021 in this issue.

23 Communication from the Commission to the European Parliament, the Council, the European Economic and Social Committee and the Committee of the Regions: A European Agenda on Migration [COM(2015) 240 final].

24 Joint Statement of the Heads of Government of the Visegrád Group Countries. Prague, $4^{\text {th }}$ September 2015. 


\section{Protecting the borders and preserving Schengen}

It needs to be stated upfront that the European Union's position on protecting its external borders has not changed as a result of the crisis. Over the course of the crisis, both the Schengen Borders Code and the Regulation on FRONTEX have been recodified and reformed: in the case of the Borders Code, the reason was more a consolidation of the original regulation with its numerous subsequent modifications, whereas in the case of FRONTEX, a more thorough reform was carried out (Karamanidou - Kasparek 2018: 23-25). The 2016 reform of FRONTEX - envisioned by the 2015 Agenda - transformed the organisation into the European Border and Coast Guard Agency (although still known as FRONTEX), with increased personnel and an equipment pool, as well as a considerably widened mandate, now covering much more than the coordination of national border guard operations, including combating cross-border crime, taking part more substantively in return operations, support to national authorities in migration management as well as an express legal basis for search and rescue operations. Contrary to the original reform proposals of the Commission however, it did not introduce a right for FRONTEX to 'intervene' in a Member State by its own decision, without the request of the Member State. Instead, it is not the Agency but the Council that may, on a proposal from the Commission, adopt an implementing act, identifying measures to mitigate serious migratory risks in a Member State, which in turn is to be implemented by FRONTEX, while the Member State concerned is required to cooperate with it in this regard. This alteration to the original concept was a result of negotiations in the Council. (Rijpma 2016: 27). ${ }^{25}$ (Nota bene: FRONTEX underwent yet another reform since then, in 201926).

From among the V4, Hungary had been most outspokenly critical of the EU's response to the crisis in the context of border security. This led Hungary to take unilateral measures, sometimes communicating the measures as a reinforcement of Hungary's historic role as the 'Bastion of Europe' (Glied - Pap 2016: 140). In more legal terms, the Hungarian government often emphasised the issue of abuse of legal migration channels and asylum procedures ${ }^{27}$ this, coupled with the unprecedented migratory pressure, led to the adoption of a number of related measures.

$25 \mathrm{Cf}$. Article 19 of the Schengen Borders Code for the adopted version.

26 Regulation (EU) 2019/1896 of the European Parliament and of the Council of 13 November 2019 on the European Border and Coast Guard and repealing Regulations (EU) No 1052/2013 and (EU) 2016/1624 (OJ 2019 L 295).

$27 \mathrm{Cf}$. for example already the Hungarian Migration Strategy adopted before the crisis by Government Decision 1698/2013. (X. 4.), which names combating abuse of legal migration channels and asylum procedures as one of the main principles of the strategy. 
In 2015, at the height of the crisis, which entailed truly unprecedented migratory pressure for Hungary, the Hungarian government initiated and later completed the building of a protective border fence along its external border with Serbia; in autumn 2015, the Hungarian Parliament introduced a number of legislative changes, the most far-reaching one being the introduction of the concept of 'crisis situation caused by mass migration' (Nagy 2016: 1047), granting certain exceptional governmental powers. ${ }^{28}$ Hungary modified its national asylum and immigration laws in a way that raised concerns regarding due process and, especially, the right to a judicial remedy; judicial appeals procedures against decisions rejecting asylum applications no longer have any suspensive effect, i.e. in practice applicants are required to leave the territory of Hungary before the time limit for lodging an appeal expires, or before their appeal has been heard (Drinóczi - Mohay 2018: 99).

The institution of 'transit zones' was also introduced, which were located in Hungarian territory along the border fence. A variety of Hungarian officials served in the zones, registering arrivals and processing asylum claims in an expedited way, via a fast border asylum procedure that was only applicable in the transit zone (Nagy 2016: 1048). ${ }^{29}$ The transit zones and the related procedures led to a number of court cases at the international and supranational levels.

In its judgment regarding the case of Ilias and $\mathrm{Ahmed}^{30}$, the European Court of Human Rights (ECtHR) made a number of important statements about the Hungarian situation, contrasting it with the obligations enshrined in the European Convention on Human Rights (ECHR). Firstly, it determined that the conditions at the transit zone itself were neither inhumane nor degrading and thus not in contravention of the prohibition of such treatment (guaranteed by Article 3 ECHR). Secondly, the ECtHR found that the lack of procedural safeguards regarding expulsion decisions did infringe the right to right to an effective remedy (Article 13 ECHR) and, indirectly, Article 3 ECHR as well, as the legal rules offered no effective protection against such expulsion decisions which could ultimately lead to chain-refoulement (Drinóczi - Mohay 2018: 105-106). Thirdly, the ECtHR ruled that the applicants' right to liberty and security (Article 5 ECHR) had also been infringed in relation to the rules on leaving the transit zone, as the fact that they were effectively only able to leave Hungary in the direction of Serbia, which entailed for them a risk of refoulement, was

\footnotetext{
28 The legislative changes were introduced by Act CXL of 2015.
}

29 The rules have subsequently been amended by Act XX of 2017 on amending certain laws related to the strengthening of the procedure conducted in the guarded border area, with the result that, in principle, all asylum applications submitted in Hungary needed to be lodged in the transit zones at the Serbian-Hungarian border. This also contributed to the infringement action being lodged by the Commission against Hungary at the CJEU. See in this regard the judgment in Case C-808/18 mentioned below, where the CJEU found a violation of EU asylum law.

30 Case of Ilias and Ahmed v. Hungary (Application no. 47287/15), judgment of $14^{\text {th }}$ March 2017. 
a de facto restriction on their right to liberty - that, coupled with the fact that the applicants received no formal decision amounted to an infringement of their human rights (Drinóczi - Mohay 2018: 107). The Ilias and Ahmed judgment was appealed by the Hungarian government. The Grand Chamber of the ECtHR ruled on the appeal in 2019 and came to a partly different conclusion: it overturned the previous judgment's finding as regards the right to liberty and security, stating that Article 5 ECHR hadn't been applicable to the situation of the applicants; the Grand Chamber emphasised the voluntary nature of the applicants' decision to enter Hungary via Serbia, to where they could freely return without any direct threat to their life or health. ${ }^{31}$ The infringement of Article 13 ECHR in conjunction with Article 3 was also overturned, albeit for procedural reasons, as the lodging of the application had exceeded the six-month time limit laid down by the ECHR. The partly different ruling was, not surprisingly, regarded by the Hungarian government as a victory for the sovereign right to protect the borders of a state. ${ }^{32}$

This was, however, soon followed by a case before the Court of Justice of the European Union (CJEU) where a legal dispute between asylum seekers and Hungarian authorities was the subject of a preliminary ruling procedure. ${ }^{33}$ Among other things, the CJEU held that the obligation imposed on third-country nationals to remain permanently in the transit zone in fact amounted to 'detention' in the context of the EU's Returns Directive, as well as the Directive laying down standards for the reception of applicants for international protection, ${ }^{34}$ to this end it distinguished the situation specifically from the Ilias and Ahmed ruling, emphasising that the asylum seekers could only have left the transit zone in the direction of Serbia by infringing Serbian law, committing an offence - meaning that it was not logical to consider them being able to regain their liberty. It also ruled that the provision contained in the modified Hungarian asylum law ${ }^{35}$ allowing for an application for asylum to be rejected as inadmissible on the ground that the applicant arrived on the territory of Hungary via a state in which that person was not exposed to persecution or a risk of serious harm (i.e. a 'safe third country') is precluded by EU law, specifically the Asylum Procedures Directive. ${ }^{36}$

31 Case of Ilias and Ahmed v. Hungary, Grand Chamber judgment of 21 ${ }^{\text {st }}$ November 2019.

$32 \mathrm{Cf}$. for instance the statement made to the press by Hungarian justice minister Judit Varga. https:// magyarnemzet.hu/belfold/varga-judit-a-szuveren-hatarvedelem-ugyeben-a-strasbourgi-birosag-akormanynak-adott-igazat-7517861/ ( th $^{\text {th }}$ March 2021)

33 Joined Cases C-924/19 PPU and C-925/19 PPU. FMS and Others v Országos Idegenrendészeti Főigazgatóság Dél-alföldi Regionális Igazgatóság and Országos Idegenrendészeti Főigazgatóság (EU:C:2020:367).

34 Directive 2013/33/EU of the European Parliament and of the Council laying down standards for the reception of applicants for international protection (OJ $2013 \mathrm{~L} \mathrm{33).}$

35 Act of LXXX of 2007 on Asylum.

36 Directive 2013/32/EU of the European Parliament and of the Council of 26 June 2013 on common procedures for granting and withdrawing international protection (OJ $2013 \mathrm{~L} 180$ ). 
It is not surprising that this judgement was less warmly received by the government, but nevertheless it acted upon it quickly. The rapid changes included the closing of the transit zones, and a full revision of the applicable asylum procedures. According to this new system ${ }^{37}$, asylum applications can only be submitted in the territory without any further requirement if the applicant is already enjoying subsidiary protection in Hungary, or is a family member of a person enjoying international protection in Hungary, or, finally, if he or she is subjected to a law enforcement measure affecting his or her liberty. For all other applicants, a so-called declaration of intent is first required, the declaration needs to be addressed to the Hungarian asylum authority but submitted in person - at diplomatic representations of Hungary located in neighbouring states outside of the Schengen Area - this in practice means either Belgrade or Kiev. The Hungarian asylum authority will examine the declaration, and subsequently inform the embassy whether or not to issue a travel document to the applicant, with which the applicant may travel to Hungary and declare their intent to apply for international protection, which will then be processed.

It should be noted that the system was introduced as a temporary one applicable as long as the 'state of danger' declared on 11 March 2020 via Government Decree 40/2020. (III. 11.) related to the Covid-19 pandemic lasted. However, in summer 2020, the Hungarian Parliament adopted a new act ${ }^{38}$ which extended the new procedure to 30 June $2021 .{ }^{39}$ In its current form, it raises a number of legal problems by placing restrictions on the right to apply for asylum and the introduction of a pre-screening of a dubious nature - at the same time, it should be noted that the CJEU ruling did not pronounce the transit zones illegal as such, thus their existence could have been maintained subject to the modification of a number of Hungarian rules (Nagy 2020: 6). In fact, there seems to be no international law or EU law obstacle (nor an obligation) to setting up such zones (Tóth 2020: 1-3), it could even be argued that their existence is even allowed, implicitly, under the Asylum Procedures Directive. ${ }^{40}$ On the other hand, the European Commission has already initiated an infringement procedure against Hungary because of the new asylum mechanism which - in the Commission's view - infringes the EU Charter of Fundamental Rights as well as the Asylum Procedures Directive. ${ }^{41}$

37 Government Decree 233/2020. (V. 26.).

38 Act LVIII of 2020 on Transitional Provisions related to the Termination of the State of Danger and on Medical Preparedness.

39 During the writing of this paper - on 26 February 2021 - the 'state of danger' in Hungary has once again been extended for an additional 90 days. See: https:/telex.hu/english/2021/02/25/parliament-extends-covid-19-state-of-danger-again (05 March 2021)

$40 \mathrm{Cf}$. Article 43 of said directive regarding border procedures.

41 https://ec.europa.eu/commission/presscorner/detail/en/inf_20_1687. 
Hungary's infringement of the EU return and asylum acquis was expressly pronounced in December 2020 as the result of an infringement procedure brought by the European Commission - the fact that by then the transit zones were no longer in operation had no effect on the judgment, as the CJEU examines the facts and the law as they stand at the time of the initiation of the procedure. ${ }^{42}$ FRONTEX has since announced that as Hungary is failing to comply with said CJEU ruling, it will suspend operations in the country entirely for an indefinite period - the first time it has done so in relation to an EU Member State. ${ }^{43}$ Ironically, FRONTEX itself is currently under scrutiny and criticism for allegedly conducting illegal push-backs of immigrants (European Parliament 2020: 1) ${ }^{44}$

The relevance of this issue as regards the other V4 countries is perhaps somewhat less obvious, but all of them have been subject to criticism.

Similarly to Hungary, Poland has emphasised that it offers strong support to FRONTEX (the headquarters of which happen to be in Warsaw) as its primary contribution to solidarity with EU initiatives (Goździak - Main 2020: 4). Poland was condemned by the ECtHR in the M. K. case for infringing Article 4 of Protocol No. 4 of the ECHR, which prohibits collective expulsion: this also applies to non-admission and rejection of asylum applications at the border crossing points, as the aim of the said provision is to prohibit states from returning a certain number of foreigners without examining their personal circumstances and therefore without enabling them to put forward their arguments against the measure taken by the relevant state authority. The absence of an effective national remedy with suspensive effect against relevant administrative decisions was also found to contravene the ECHR. ${ }^{45} \mathrm{~A}$ number of cases regarding unsuccessful applications for international protection at border crossing points have also been brought before the Polish Supreme Administrative Court and other domestic courts. ${ }^{46}$

Slovakia has been criticised for maintaining immigration detention in rather "prison-like" facilities (Global Detention Project 2019: 21) as well as obliging the third-country nationals themselves to pay the costs of their detention, food and transport. ${ }^{47}$ In a legal dispute similar to the M. K. case however, the ECtHR

42 Case C-808/18 Commission v Hungary (EU:C:2020:1029).

43 Frontex suspends operations in Hungary. EUobserver, 27 January 2021. https://euobserver.com/migration/150744 ( $5^{\text {th }}$ March 2021).

44 The Frontex Scrutiny Working Group set up by the EP held its first meeting in March 2021. Its task is to investigate and evaluate alleged fundamental rights violations by the Agency. https://www.europarl. europa.eu/news/hu/press-room/20210303IPR99105/first-meeting-of-the-frontex-scrutiny-group-with-leggeri-and-johansson.

45 Case of M.K. and Others v. Poland, Application Nos. 40503/17, 42902/17 and 43643/17, 23 July 2020, paras. 200 and 204.

46 The judgments are only available in Polish. For references see European Union Agency for Fundamental Rights 2020: 32.

47 In accordance with Articles 80(1)-(2) and 91(3) of Act 4004/2011 on Residence of Aliens. 
found no infringement of Article 4 of Protocol No. 4 of the ECHR. ${ }^{48}$ The reason for the different outcome was that in Asady and Others v. Slovakia, the collective nature of the expulsion decisions taken by Slovakia was not discernible, since individual interviews were conducted with the asylum applicants, who had an effective possibility to submit arguments against their removal; the ECtHR found that the the procedure allowed for the personal circumstances of the applicants to be taken into account genuinely and individually.

The Czech government adopted in 2015 - at the peak of the crisis - the country's Migration Policy Strategy.$^{49}$ Among its priorities, this strategic policy document mentions the need to ensure effective law enforcement and returns policy, as well as emphasising the relevance of migration control for upholding the benefits of free movement in the EU's Area of Freedom, Security and Justice (Chlupáč 2019: 207). An issue was brought to the fore in relation to the country's Foreign Nationals Act (Act No. 326/1999), which is the main legal instrument pertaining to alien policing in Czechia. The problem related to the fact that the Foreign Nationals Act did not define the concept of the risk of absconding during the 'Dublin procedure' in objective terms. This was raised in the $\mathrm{Al}$ Chodor case before the CJEU, which held in 2017 that although the Dublin Regulation permitted detention to prevent absconding, the Member States were required to define the objective criteria of the risk of absconding by law; a requirement flowing also from the Charter of Fundamental Rights of the EU (Article 6 - the right to liberty and security of person). As this was not the case in Czech law, the CJEU proclaimed it incompatible with EU law. ${ }^{50}$ Czechia subsequently amended the Foreign Nationals Act accordingly (Global Detention Project 2018: 10).

It is easy to see the tensions and the conflicts that the V4's strict approach to border control and entry has created. It is undeniable however, that, as the V4 declared in their aforementioned Joint Statement in 2015, controlling the external borders is inseparably tied to maintaining the Schengen area. The temporary but abundant reinstatement of internal border controls (which in itself is a legal possibility under the Schengen Borders Code ${ }^{51}$ ) as a response to the 2015 crisis has arguably led to a 'crisis of Schengen', even if the restrictive effects primarily targeted third-country nationals at the internal borders as well (Colombeau 2019: 640-641). The Schengen Area is a core element of the EU's Area of Freedom, Security and Justice, and is closely connected to free

\footnotetext{
48 Case of Asady and Others v. Slovakia (Application no. 24917/15).

49 Strategie migrační politiky. Available in Czech at: https://ec.europa.eu/migrant-integration/librarydoc/ strategy-on-migration-policy-of-the-czech-republic ( $5^{\text {th }}$ March 2021).

50 Case C-528/15 Salah Al Chodor and others (EU:C:2017:213). The judgement was passed in a preliminary ruling procedure.

51 For the state of play of the temporary restrictions see: https://ec.europa.eu/home-affairs/what-we-do/ policies/borders-and-visas/schengen/reintroduction-border-control_en.
} 
movement of persons for both economic and non-economic reasons. A European Parliament study has estimated the economic cost of a two-year suspension of the Schengen acquis at nearly $€ 5$ billion in the case of a suspension limited to seven states, and a staggering $€ 51$ billion in case of a suspension applicable to the entire Schengen Area; this is additional to the one-off costs arising from the physical reestablishment of border checks amounting to $€ 7.1$ billion (European Parliament 2016: 26-35).

\section{Rejecting the 'open doors' policy}

Potentially many things could be understood by the rejection of the open doors policy but considering that protecting the borders constitutes a separate policy goal, this section will focus on the relocation debate, which has led to judicial disputes in two respects. Relocation in the EU's migration and asylum policy refers to measures adopted as a direct response to the crisis in order to mitigate the pressure affecting some 'frontline' Member States. ${ }^{52}$ To address the issue, the EU has adopted two decisions. The first attempt to tackle the 'exceptional' migratory flows in the Mediterranean for the benefit of Italy and of Greece was a relocation decision based on voluntary cooperation: this was meant to entail relocating a total of 40,000 asylum seekers from Italy and Greece to other Member States, based on their voluntary commitment..$^{53}$ As the Member States agreed to implement this decision on a voluntary basis, the measure adopted by the Council did not meet serious opposition.

The Council, however, adopted a follow-up relocation decision, which introduced a binding scheme: accordingly, 120,000 persons in need of international protection would be relocated from Greece and Italy to other Member States. ${ }^{54}$ As the second decision was no longer based on voluntary participation, it met with considerable opposition: it was voted against in the Council by three of the Visegrád states, namely Slovakia, Hungary and Czechia (as well as Romania) Hungary was originally meant to be included as the third beneficiary of the decision, recognising the significant exposure of the country, but was removed at Hungary's own request as it did not want to be regarded as a frontline state

52 Relocation needs to be differentiated from resettlement, which is a separate scheme developed by the EU in cooperation with UNHCR. Resettlement involves transferring third-country nationals or stateless persons in need of international protection from a third country to an EU Member State in order to receive international protection. The EU's resettlement scheme was designed to cover 20,000 individuals, with a voluntary participation of Member States. See: Conclusions of the Representatives of the Governments of the Member States meeting within the Council on resettling through multilateral and national schemes 20,000 persons in clear need of international protection, 20 th July 2015.

53 Council Decision (EU) 2015/1523 establishing provisional measures in the area of international protection for the benefit of Italy and of Greece (OJ 2015 L 239).

54 Council Decision (EU) 2015/1601 of 22 September 2015 establishing provisional measures in the area of international protection for the benefit of Italy and Greece (OJ 2015 L 248). 
(Peers 2015:). The decision was adopted as a temporary measure, based on Article 78 (3) of the TFEU, and expired on $26^{\text {th }}$ September 2017.

\section{Judicial review of the legality of compulsory relocation}

Two of the V4 states, Hungary and Slovakia, claimed that the decision was unlawful and initiated an annulment procedure at the CJEU as a result..$^{55} \mathrm{In}$ summary, the various pleas made by the two applicants claimed that the legal basis of the measure was incorrect and that procedural errors were made in the adoption of the decision; a number of substantive pleas were also submitted. Below I will analyse the most significant ones.

The legal basis of the contested decision was Article 78(3) TFEU, which, as mentioned above, allows for the adoption of provisional measures as a response to an emergency situation involving a sudden inflow of third-country nationals. Such temporary measures may be adopted by the Council, on a proposal from the Commission and after consulting the EP.

The two applicant states claimed that Article 78(3) was in more than one way not an appropriate legal basis to adopt the measure. Hungary claimed that although the decision was adopted as a non-legislative act, based on its content and effect it should be categorised as a legislative act; ${ }^{56}$ among other things this would mean that the national parliaments of the Member States should have been consulted in the process of adoption. The Court ascertained that although the procedure described in Article 78(3) was indeed similar to one of the special legislative procedures (the consultation procedure), the provision does not contain an express reference to the special legislative procedure - and as this procedure is, according to Article 289(2) TFEU, only applicable 'in the specific cases provided for by the Treaties', it is not applicable in the context of Article 78(3).

Furthermore, Hungary and Slovakia both claimed that the adopted decision was not provisional in nature; this was quickly rebutted by the CJEU by referring to the clearly defined expiration of applicability contained in the measure itself.

As regards the procedural aspects of the decision, Hungary and Slovakia claimed that since the adopted decision had undergone substantial modifications as compared to the original Commission proposal, the Council would have been obliged to reconsult the European Parliament (as it had only been

55 Joined Cases C-643/15 and C-647/15 Slovak Republic and Hungary v Council (EU:C:2017:631). The two actions were submitted separately but merged by the Court. The annulment procedure allows the CJEU to review the legality of EU legal acts on grounds of lack of competence, infringement of an essential procedural requirement, infringement of the Treaties or of any rule of law relating to their application, or misuse of powers (see Article 263 TFEU).

56 The formal distinction between legislative and non-legislative acts was introduced by the Lisbon Treaty. Legislative acts are adopted in accordance (ordinary or special). Non-legislative acts do not follow these procedures and can be adopted by EU institutions according to specific rules. 
asked for an opinion on the original draft). This obligation is apparent from the case law of the CJEU. ${ }^{57}$ In the case at hand however, the Court found that as the President of the Council attended an extraordinary plenary sitting of the EP, and made an express statement about the one significant change in the proposal (that is, the fact that Hungary does not wish to become a beneficiary state), the EP must necessarily have taken this amendment into consideration when deciding on its consultative (i.e. not legally binding) opinion. ${ }^{58}$

In terms of substantive claims, Slovakia put forward that the decision was contrary to the principle of proportionality: it was inappropriate to achieve its goal as it would not address systemic problems in the Greek, Italian and European asylum systems, while the effectiveness of the measure in reducing migratory pressures was also questioned. The CJEU emphasised however that the legality of an EU act cannot depend on "retrospective assessments of its efficacy" and that the fact that only a small number of relocations have taken place so far did not necessarily mean that the measure had been inappropriate to achieve its goal from its inception. Hungary's plea that it should not be required to receive relocated asylum seekers because of the unprecedented burden that its own asylum system is facing was also refuted by the Court, pointing to Hungary's refusal to be included as a beneficiary of the contested decision, and thus concluding that in this light the inclusion of Hungary among the obligated states was not an infringement of the proportionality principle. ${ }^{59}$

In line with the above, the CJEU dismissed both applications. The date of the judgment was 6 September 2017 - just 20 days before the expiry of period of application of the decision. Regardless of the decision, Hungary and Slovakia consistently refused to participate in the relocation scheme - as did Poland from 2016 onwards, following a change of government (Szczerbiak 2017).

The judgement can be seen as a reaffirmation of the legal obligation of solidarity contained in Article 80 TFEU, and demonstrates that the CJEU does not see solidarity as an obligation which can be fulfilled purely by voluntarily undertaken obligations according to Member State preference (Circolo et al 2019: 172-173).

57 See particularly Case C-65/90 Parliament v Council (EU:C:1992:325).

$58 \mathrm{It}$ is interesting to note that Hungary produced as evidence two letters sent by the EP Legal Affairs Committee to the President of the EP, stating that the committee concluded that the Parliament should have been consulted again due to the substantive amendment. The Council asked the CJEU not to take these letters into account as they could only have been "improperly obtained" by Hungary. The CJEU did not feel compelled to go into this aspect (Joined Cases C-643/15 and C-647/15, paras 156-158).

59 Another V4 state, Poland intervened in the proceedings in support of the applicants and claimed in this context more broadly that the relocation quotas would cast a significantly heavier burden on those Member States which are "virtually ethnically homogeneous, like Poland", referring to cultural differences. The Court pointed firstly to the fact that this statement was inadmissible as it went way beyond the submissions of the applicants, and secondly reaffirmed that any considerations based on ethnic considerations were contrary to Article 21 of the EU Charter of Fundamental Rights (Joined Cases C-643/15 and C-647/15, paras 302-309). 
As regards the obligation to reconsult the Parliament: while it cannot be denied that the Parliament ought to have been de facto aware of the substantive amendment, it is questionable whether in legal terms a statement made at a plenary hearing is sufficient to satisfy the requirement of formal reconsultation, an obligation which was reaffirmed by CJEU judgments and regulated accordingly by the Rules of Procedure of the EP itself. ${ }^{60}$ (Nota bene: the EP in this case did not argue against the illegality of the decision based on this - or any other - reason.)

\section{Infringement actions for non-compliance with compulsory relocation obligations}

Not long after the unsuccessful annulment actions, the European Commission initiated infringement procedures against Poland, Czechia and Hungary for the non-fulfilment of the obligations under the second relocation decision. The three V4 states intervened in support of each other in the relevant procedures, which were merged by the CJEU. ${ }^{61}$ All three states claimed that the action was inadmissible, as the applicability of the legal act in question had already expired, thus the infringement actions against them were 'devoid of purpose'. The Court held however that the infringement action's aim is an objective determination of whether a Member State has failed to fulfil its obligations under the EU law; an objective which the Commission has a vested interest in, in line with the primary law of the EU.

As regards the merits, the Court did not have a difficult time in finding an infringement vis-à-vis all three states, as regards the fact that the states have definitely not relocated any individuals. The substantive counterarguments of the Member States related in essence to the allegation that relocation posed a risk for the maintenance of law and order and the safeguarding of internal security in the context of Article 72 TFEU (Poland, Hungary) or public security (Czechia). The Court refuted these arguments by proclaiming that the derogation contained in Article 72 TFEU must be interpreted strictly, and that the scope of the concept of law and order and internal security cannot be determined by the Member States unilaterally. Also, reliance on internal or public security as a basis of restrictive measure's needs, according to settled case law of the CJEU, to rely on consistent, objective and specific evidence pertaining to the individual in question, investigated on a case-by-case basis. Thus, invoking Article 72 TFEU for the sole purpose of general prevention, i.e., the en bloc refusal to take part in relocation, does not satisfy these requirements. The alleged ineffectiveness

60 See Rule 61 (Renewed referral to Parliament) of the Rules of Procedure of the European Parliament ( $9^{\text {th }}$ parliamentary term - December 2019).

61 Joined Cases C-715/17, C-718/17 and C-719/17 Commission v. Republic of Poland and others (EU:C:2020:257). 
of the relocation scheme to address the effects of the asylum crisis, cited by Czechia, was also dismissed by the Court, as a purported lack of effectiveness of a measure did not affect its obligatory nature as a binding legal act. The Court thus found that Poland, the Czechia and Hungary had infringed their obligations under EU law.

Even though the legal consequences of this judgment are declaratory (as the application period expired, no financial penalty payment under Article 260 TFEU could possibly be sought by the Commission), it nevertheless serves to reaffirm the formal rule of law and the binding nature of EU legal acts, including Council decisions adopted as temporary measures - lawfully adopted supranational EU law is binding, regardless of political disagreement (Krist 2020).

Although it will not be analysed here in detail, it is worth mentioning that in contrast to the relocation scheme, the 2015 EU-Turkey deal ${ }^{62}$ was vocally supported by the V4, as evidenced by the Joint Declaration made by the V4 Prime Ministers on $8^{\text {th }}$ June 2016; the deal, among others, contained a reaffirmed and extended version of the resettlement scheme originally envisaged in the 2015 Migration Agenda (Weber 2016: 34-36).

The relocation debate started as a political argument that led to judicial disputes. In the end, the legality and binding nature of the scheme was upheld, which led to a declaration of infringement by three of the V4 countries. The CJEU rightly pointed out that the level of effectiveness of a measure had no effect on its legally binding nature, but it is nonetheless true that the implementation of the relocation scheme in general was far from effective, as the total number of relocated persons amounted to 27,695, as opposed to the envisaged 120,000 (European Commission 2017:1).

In any case, the opposition of the $\mathrm{V} 4$ to relocation as a solution to the crisis can be seen as an important factor in gradually changing the approach of other Member States such as Germany and, ultimately, the European Commission (Duszczyk et al 2019: 483-485). (This occurrence will be relevant for approach of the 2020 proposals of the Commission - see Part 3.)

\section{Effective management of the root causes of migration flows}

The final V4 priority to look at concerns the approach that emphasises aiding and assisting countries of origin or 'output' countries regarding migration, instead of focusing on resettlement, relocation or legal channels into the EU. This involves providing aid and assistance to relevant third countries to address not migration itself, but its root causes.

62 EU-Turkey statement, 18 ${ }^{\text {th }}$ March 2016 https://www.consilium.europa.eu/en/press/press-releases/2016/03/18/eu-turkey-statement/. 
The EU is strongly involved in humanitarian aid and development cooperation. In general, and in the global context, the EU is actually the leading donor of humanitarian aid - between 2014-2020, EUR 7.1 billion was allotted for this policy, coupled with EUR 19.6 billion for the Development Cooperation Instrument (DCI), which finances multiannual development cooperation programmes, focusing primarily on poverty reduction and sustainable development, and EUR 2.3 billion for the Instrument contributing to Stability and Peace (Burnay et al 2016: 14). The TFEU contains a separate legal basis for humanitarian aid activities in Article 214. This EU competence is a shared competence, but one that is subject to a special rule: the EU measures in this field do not prevent the Member States from exercising their own competences. ${ }^{63}$

Addressing the root causes of migration towards the EU through development cooperation and humanitarian assistance is furthermore one of the key actions listed in the 2015 Migration Agenda, and an additional EUR 30 million was pledged for Regional Development and Protection Programmes in North Africa, the Horn of Africa, and the Middle East (Agenda 2015: 4). In November 2015, the European Union Emergency Trust Fund (EUTF) for Africa was established to "provide an integrated and coordinated response to the diverse causes of instability, irregular migration and forced displacement"64; with the participation of the EU, 25 of its Member States, as well as Norway and Switzerland. The V4 countries have all signed the programme's Constituent Agreement. ${ }^{65}$ In 2016, an EU agreement was signed with Egypt on a programme to inter alia address the root causes of migration, with a budget of EUR 60 million (Al-Kashef \& Martin 2019: 7).

The goal to provide humanitarian aid in the crisis-stricken countries has been a consistently and transparently articulated policy aim of the V4 throughout the initial crisis and beyond (Nyizo 2017: 82). The V4 state to put this goal into practice most visibly was Hungary, but all V4 states share the policy objective and have taken appropriate measures to implement it.

In 2013, Hungary set up a government-funded scholarship program called Stipendium Hungaricum. According to its constituent legal act, Government Decree $285 / 2013$ (VII. 26.) ${ }^{66}$, its aim is to support foreign students' studies in Hungarian higher education institutions, in line with the pragmatic Hungarian foreign policy strategy aims of the 'Eastern opening' and 'Southern opening' (Tarrósy - Vörös 2020: 124-125). The Stipendium Hungaricum programme is based on bilateral educational cooperation agreements signed between the ministries responsible

\section{See Article 4(4) of the TFEU.}

64 https://ec.europa.eu/trustfundforafrica/content/about_en

65 Agreement Establishing the European Union Emergency Trust Fund for Stability and Addressing Root Causes of Irregular Migration and Displaced Persons in Africa, 2015 https://ec.europa.eu/trustfundforafrica/sites/euetfa/files/original_constitutive_agreement_en_with_signatures.pdf

66 The decree is accessible here (in Hungarian): https://net.jogtar.hu/jogszabaly?docid=a1300285.kor 
for education in the sending countries and Hungary. There are currently nearly 70 non-European eligible countries, including states such as Yemen, Eritrea and Iraq, which are significant source countries of migrants and asylum seekers. ${ }^{67}$

Focusing more specifically on crisis regions, the Hungarian Government also set up the Scholarship Programme for Christian Young People (SCYP) in 2017. ${ }^{68}$ The core aim of the SCYP is to provide study opportunities to young Christians living in crisis areas where they are exposed to religious persecution or lack the freedom to pursue the religion of their choosing, 'in order to contribute to the social appreciation of professionals returning to their home countries' ${ }^{69}$ The SCYP is currently managed by the Hungary Helps Agency. ${ }^{70}$

The Hungary Helps Agency is a part of the 'Hungary Helps Programme' (HHP). The HHP was initiated by in 2018 and is the country's most significant humanitarian aid and development programme, with the goal of providing assistance to persecuted Christians.$^{71}$ The Hungary Helps Agency is a government agency operating in the legal form of a non-profit limited liability company that manages the HHP. The agency provides aid for activities such as obtaining and delivering medical care and medical supplies, reconstructing buildings and infrastructure destroyed by armed conflicts and natural disasters, the promotion of the freedom of religion, and the establishment of training and educational institutions. ${ }^{72}$ Although the main focus of the HHP is to assist Christian communities facing persecution in their home countries, non-Christians also receive support from the HHP initiatives, as hospitals, schools, etc. naturally provide services regardless of religious affiliation (Vékony 2019: 13; Fischl 2019: 265). As a special rule in the context of the Hungarian asylum process, in the event that an asylum applicant refers to persecution due to his or her Christian religion, the minister responsible for implementing the Hungary Helps Program is appointed as special authority to investigate said reason. ${ }^{73}$

An analogous programme called SlovakAid has been implemented by Slovakia, this initiative also focuses on providing humanitarian aid and financing development projects in countries including Afghanistan, Kenya, Eritrea and Somalia. ${ }^{74}$ In Slovakia's case, the aid framework originated much earlier, in

67 See the list at https://stipendiumhungaricum.hu/partners/

68 Government Decree 120/2017. (VI. 1.).

69 Scholarship Programme for Christian Young People' - Operational Regulations effective from 28 February 2020, p. 4 (https://tka.hu/docs/palyazatok/20200228_okf_jav_en_honlapra.pdf)

70 As regulated by Government Decree 365/2020. (VII. 28.)

71 Act CXX of 2018. Available in English at https://hungaryhelps.gov.hu/wp-content/uploads/2019/08/ Act-CXX-of-2018.pdf.

72 See Section 2 of Act CXX of 2018.

73 See Section 2/A. $\$$ b) of Government Decree 301/2007 (XI.9.) on the implementation of the Act on Asylum

74 https://slovakaid.sk/?lang=en. 
2003, but received additional relevance in the context of the 2015 crisis; the strategic reasons motivating the Slovakian aid policy of 2014-2018, for instance, named illegal migration as a significant factor (Profant 2018: 379-380).

In Czechia, a similar scheme exists as well: the country's development program is managed by the Czech Development Agency, also known as CzechAid. The underlying national strategy points out, among other things, that migration push factors from developing countries often include the search for economic opportunities, and that development cooperation and security building measures can contribute to preventing forced migration. ${ }^{75}$ In 2019, the Czech government announced a pledge of CZK 700 million (circa EUR 27 million) to be made available to African output countries of migration: the sum is intended to be spent on humanitarian aid, stabilisation and socio-economic development, thereby also limiting migratory pressures on Europe; the Czech government named Ethiopia, Mali and Morocco as priority states in the scheme. ${ }^{76}$ The Czech government also provides higher education scholarships for students from developing countries. ${ }^{77}$

The Republic of Poland runs Polish Aid, a development cooperation programme established in 2011 and coordinated by the Ministry of Foreign Affairs. ${ }^{78}$ The measures taken in aid of developing countries include humanitarian aid and development funding, while the relevant strategic document mentions the risk of unrestricted, economically motivated migration as one of the (many) reasons behind the aid programme. ${ }^{79}$

Finally, it is worth mentioning that the V4 have initiated a four-year long joint development project in Kenya under the EUTF. The project focuses on improving social and economic conditions of small-scale holder farmers in the country (Chmiel 2018: 24).

The humanitarian and development aid policies of the EU as a whole and those of the V4 states show complementarity, rather than conflict. As regards the division of competence, this is also a consequence of the non-pre-emptive nature of the EU's powers in this field, but the same conclusion can be drawn from

75 Ministry of Foreign Affairs of the Czech Republic: Development Cooperation Strategy of the Czech Republic 2018-2030 (p. 16 and 19). http://www.czechaid.cz/wp-content/uploads/2016/09/CZ_Development_Cooperation_Strategy_2018_2030.pdf.

76 Radio Prague International: Prague to send millions to African states to help prevent migration to EU. 08/19/2019 https://english.radio.cz/prague-send-millions-african-states-help-prevent-migration-eu-8123003

77 https://www.msmt.cz/eu-and-international-affairs/government-scholarships-developing-countries?lang=2.

78 See the Development Cooperation Act of 16 September 2011. Available in English at: https://www.gov. $\mathrm{pl} /$ attachment/0d4493f7-2d7a-470a-8925-72a0a0ef8294.

79 Multiannual Development Cooperation Programme 2016-2020, https://www.gov.pl/attachment/ 181a8d66-439 b-49b8-b903-63124ffaa30a; Solidarity for Development. The Multiannual Programme for Development Cooperation for 2021-2030 https://www.gov.pl/attachment/0d836bf6-849c-4307-b5761cef66767f36. 
a comparison of the policy goals, as both levels aim to reduce push factors in the countries of origin in order to reduce migration pressure on the EU. In terms of the rationale, the V4's measures are occasionally more vocally communicated as an alternative to migration in general, and the need to combat religious persecution, especially persecution of Christians, is emphasised. These programmes had already been established before the crisis, thus their goal is not only to mitigate the consequences thereof. It demonstrates that the $\mathrm{V} 4$ are willing to finance humanitarian projects in developing countries regardless of the volume of migration.

To summarise all of the points elaborated upon in Part 2: the EU's and the V4's responses to the crisis show a mixed and often confrontational picture. On the one hand, a number of national measures relating to procedures at the borders, relocation and detention have been inconsistent with EU law and international human rights obligations - even if the general approach (i.e. protect the external borders inter alia in order to maintain the internal dimension of Schengen) is, at least in theory, not divergent. On the other hand, in the field of humanitarian aid and development cooperation, a pleasing complementarity can be observed - of course, the competence situation in the latter field is different from the AFSJ to begin with.

\section{The new pact - the way forward?}

The 2015 crisis and its (legal and political) aftermath led the European Commission to propose a reform of the Common European Asylum System in 2016 the six-pack of proposals contained initiatives to reform all elements of EU asylum law, notably proposing a reform of the Dublin system to include a permanent relocation mechanism applicable in crisis situations, similar to the one contained in the temporary decision analysed above, based on a redistribution quota. ${ }^{81}$ The Dublin reform proposal was among the most disputed elements of the package, notably and vocally opposed by the $\mathrm{V} 4^{82}$, which led to a negotiation deadlock in the Council beginning in 2016 (Pollet 2019).

Following years of stalemate, the Van Der Leyen Commission proposed a New Pact on Migration and Asylum (hereinafter: New Pact) in September 2020.83

80 Legislative train schedule: Reform of the Common European Asylum System (CEAS) https://www.europarl.europa.eu/legislative-train/theme-towards-a-new-policy-on-migration/file-reform-of-the-common-european-asylum-system-(ceas) (5 $5^{\text {th }}$ March 2021).

81 Proposal for a regulation establishing the criteria and mechanisms for determining the Member State responsible for examining an application for international protection lodged in one of the Member States by a third-country national or a stateless person [COM(2016) 270 final].

82 Euractiv: Visegrád countries oppose Commission's revamped asylum policy. https://www.euractiv.com/ section/justice-home-affairs/news/visegrad-countries-oppose-commissions-revamped-asylum-policy/ ( $5^{\text {th }}$ March 2021).

83 Communication from the Commission to the European Parliament, the Council, the European Economic and social committee and the Committee of the Regions on a New Pact on Migration and Asylum [COM(2020)609 final]. The Annex of the Pact also contains an implementation roadmap. 
The New Pact was meant to break the political deadlock and allow, finally, for the establishment of a reformed framework for migration and asylum; to this end it - as a change of narrative - acknowledged that the 2015 crisis raised some legitimate, genuine concerns as well, and also unearthed a number of differences between the Member States that needed to be 'acknowledged and overcome' ${ }^{84}$

At the core of the New Pact are a number of legislative proposals to adopt new measures or modify previously existing ones, supported by some non-binding recommendations. The Pact partly builds on previous proposals of the Commission: it retains the initiative to set up and EU Asylum Agency, to reform the Qualification Directive, the Reception Conditions Directive and the Returns Directive, as well as the establishment of a permanent EU Resettlement Framework. However, it also proposes new instruments, some of which are especially relevant from the perspective of this paper. These include a proposal for a regulation on a screening procedure at the external borders in order to identify the relevant (asylum or return) procedure applicable to the individual in question, ${ }^{85}$ and a revision of the proposed Asylum Procedures Regulation ${ }^{86}$ to include, among other things, rules on a new 'border procedure', i.e. a fast-tracked procedure to assess asylum claims that have a low chance of being accepted without requiring legal entry to the territory of the EU Member States ${ }^{87}$, as well as a return border procedure applicable to persons whose applications have been rejected in the context of the border procedure for asylum. The New Pact also encompasses a proposal for a new Asylum and Migration Management Regulation ${ }^{88}$ which would replace the much-debated Dublin Regulation entirely - and establish a 'solidarity mechanism' that takes a wider approach to solidarity as a concept. The new solidarity mechanism would not only contain a permanent a relocation system in case of a high migratory pressure similar to the relocation quota proposed in 2016 (applicable only to asylum seekers who are not subject to the border procedure outlined above), but would also intro-

84 New Pact, p. 1.

85 Proposal for a Regulation of the European Parliament and of the Council introducing a screening of third country nationals at the external borders and amending Regulations (EC) No 767/2008, (EU) 2017/2226, (EU) 2018/1240 and (EU) 2019/817 [COM/2020/612 final].

86 Amended proposal for a Regulation of the European Parliament and of the Council establishing a common procedure for international protection in the Union and repealing Directive 2013/32/EU $[\mathrm{COM} / 2020 / 611$ final]. This would replace the Asylum Procedures Directive currently in force. Changing the form of the legal act from a directive to a regulation means direct applicability of the EU rules and less discretion on behalf of the Member States as compared to the implementation of a directive.

87 "This would apply to claims presented by applicants misleading the authorities, originating from countries with low recognition rates likely not to be in need of protection, or posing a threat to national security. Whilst asylum applications made at the EU's external borders must be assessed as part of EU asylum procedures, they do not constitute an automatic right to enter the EU. The normal asylum procedure would continue to apply to other asylum claims and become more efficient (...)." (New Pact, p. 4.)

88 Proposal for a Regulation of the European Parliament and of the Council on asylum and migration management [COM/2020/610 final]. 
duce 'return sponsorship' regarding illegally staying third-country nationals as an alternative form of solidarity. ${ }^{89}$ The New Pact also contains a regulation to address crisis and force majeure situations, introducing an immediate protection status and also making use of the solidarity system mentioned above. ${ }^{90}$ The more nuanced approach to solidarity can be seen as move away from the indivisibility of the solidarity obligation presented in the 2017 CJEU ruling against Hungary and Slovakia (Karageorgiou 2020: IV), as well as an intention to take views such as that of the V4 into account.

At first glance, the New Pact seems to address most of the points of contention between the V4 and the general EU approach. It seeks to establish a procedure to be conducted at the border of the EU in order to prevent abuse of asylum procedures by illegal migrants. It offers alternatives as to the form of contribution to solidarity ${ }^{91}$ in migration and asylum management in 'pressure' situations. It proposes a dedicated crisis management measure. It has even received criticism from NGOs for overemphasising securitisation inter alia by removing the principle that detention should only be applied as a last resort measure in border procedures (ECRE 2020). As some elements of the package of proposals can be seen as a concession towards the V4's policy preferences (Abdou 2021:10), it would not seem too far-fetched to expect a more positive response from critics of the 2015 Agenda and the EU's general approach.

However, the V4 soon made it clear that they were not in full support of the New Pact. The V4 (supported in this case by Estonia and Slovenia) issued a non-paper in December 2020 outlining what they could support - and what they could not - from among the package of proposals.$^{92}$ In their joint position, the states outlined that they agreed with more of an emphasis being laid on the external dimension of migration and asylum, but suggested further exploration of the concept of establishing regional disembarkation platforms outside the EU. They stressed the importance of a more effective returns policy (which is undisputedly not the current situation), and, even more, the need to have robust border protection. In the latter context, the V4 argued for the pre-entry screening procedure to be applied to all illegal migrants in order to identify and

89 Apart from return sponsorship, a further solidarity alternative is the financing of 'capacity-building measures in the field of asylum, reception and return, operational support and measures aimed at responding to migratory trends affecting the benefitting Member State through cooperation with third countries.' See Articles 45-56 of the proposal for the details of the solidarity mechanism.

90 Proposal for a Regulation of the European Parliament and of the Council addressing situations of crisis and force majeure in the field of migration and asylum [COM (2020) 613 final]. This measure would repeal the Temporary Protection Directive (2001/55/EC) which had never been activated since is adoption in 2001 (OJ 2001 L 212).

91 Although it is disputed by some whether return sponsorship truly constitutes a form of solidarity. See e.g. Sundberg Diez - Trauner 2021: 8-11.

92 New Pact on Migration and Asylum. Joint Position of Poland, Hungary, Slovakia, Czech Republic, Estonia and Slovenia. 10 December 2020 https://www.visegradgroup.eu/download.php?doclD=457 (5 $5^{\text {th }}$ March 2021). 
register them, and for the border procedure to be applied as broadly as possible, including too vulnerable groups. According to the V4, the security, public order and public health interests of the EU (and its Member States) should take priority in regulating pre-entry procedures. They have also rejected the proposed basis (GDP and population) of the relocation quota and maintained that any relocation scheme should be based on voluntary participation.

It is true that the border procedure would not apply to all asylum seekers and illegal migrants. It is also true that relocation still plays a crucial part in the solutions proposed by the Commission. However, the more elaborate approach to solidarity, and the reinforced security aspects could have merited a more positive approach by the V4. Of course, their non-paper cited above does state that their commonly articulated position is intended to serve as 'constructive input for making further progress in the negotiations on the Pact', even if a compromise allowing the EU to move forward still seems rather elusive for now.

\section{Concluding remarks}

The 2015 crisis has been a watershed moment for EU migration and asylum law and policy. It has brought to the fore a number of political differences that have led to legal disputes, touching upon a range of issues connected to border management, human rights and solidarity. Both the CJEU and the ECtHR have deemed some of the V4's legislative and policy responses contrary to a number of international and EU legal standards. On a related note, however, the consistently articulated policies of the V4 in this policy field have led the European Commission to propose a more nuanced and flexible legislative package to move forward with the long-delayed reform of EU migration and asylum law.

Although since 2020 the Covid-19 pandemic has understandably become the main legal and political focus of European crisis management, migration remains high on the agenda of the EU. ${ }^{93}$ Even in light of the more balanced approach of the New Pact, a compromise seems difficult to reach, inter alia as the pack of proposals is facing criticism from NGOs and academics for being overly restrictive, and at the same time from the V4 and other states for still being too permissive with migration and not flexible enough in terms of Member State obligations.

While the focus on securitisation and externalisation is definitely the most perceivable element of the Visegrád approach, their interest in maintaining the internal benefits of Schengen (i.e. avoiding the reintroduction of internal border controls) can at least partly explain the policy direction; especially bearing in mind proposals relating to a form of mini-Schengen of Western European

93 The two phenomena are even interrelated in a number of aspects, as evidenced by the New Pact - see the provisions on preliminary health checks in the proposed Screening Regulation, and numerous references to Covid-19 in the proposed regulation on crisis and force majeure situations. 
Member States which would maintain true open borders amongst the participants, but control their external borders more strictly (Szalai et al 2017: 20). To be a part of Schengen is a crucial policy goal that the V4 have articulated and taken political and legal measures towards even before their EU membership and continued to treat it as a high priority until their full integration into the acquis in 2007 (Bauerová 2018b: 124-125). It is understandable that they are equally keen to preserve this achievement. Of course, this cannot come at any cost: migration, and especially asylum have a human rights dimension which needs to be considered.

In our analysis, we have also found one area without any friction in a legal sense: humanitarian aid and development cooperation policy. Even if the related rhetoric of the V4 and the EU is not entirely congruent, there seems to be general agreement as to the high relevance of this field - and its potential to mitigate migration pressure. The fact that the most of the corresponding initiatives of the V4 predate the crisis shows that this policy is not regarded merely as a crisis management tool.

In 2021, the Visegrád Group celebrates the $30^{\text {th }}$ anniversary of its establishment. In the celebratory joint statement, the V4 have emphasised the value of their common position to strengthen the external borders and focus on aid and development projects in Africa as a response to the 2015 crisis. ${ }^{94}$ As such, there is no legal concern with such a policy approach. It may even be argued that the V4 could attempt to take on more of a leadership role in migration and asylum law and policy in some aspects (Karabegović 2020). It is also true that, to quote Malcolm Shaw, "[1] aw and politics cannot be divorced. They are not identical, but they do interact on several levels. They are engaged in a crucial symbiotic relationship. It does neither discipline service to minimalise the significance of the other" (Shaw 2017: 49). That being said, policy considerations cannot take precedence over binding EU law and the obligations flowing from it, and no form of solidarity - however flexible - can exist without loyalty to EU law (Goldner Lang 2020: 59). In a supranational organisation based on the rule of law, there can be no question of that.

With the Czech Presidency of the Council coming up in the second half of 2022, perhaps one can be hopeful that the EU and its 'renegade' ${ }^{95}$ members can reach a compromise which is both politically acceptable - and legally sound.

The publication was supported by the University of Pécs, Szentágothai Research Centre, Research Centre of Historical and Political Geography and PADME Foundation.

\footnotetext{
94 Declaration of the Prime Ministers of the Czech Republic, Hungary, the Republic of Poland and the Slovak Republic on the Occasion of the $30^{\text {th }}$ Anniversary of the Visegrád Group. 17 February 2021 https://www. visegradgroup.eu/calendar/2021/declaration-of-the-prime (5 $5^{\text {th }}$ March 2021).

95 The term was borrowed from Boldizsár Nagy (Nagy 2017).
} 


\section{References}

Abdou, Leila Hadj: From the Migration Crisis to the New Pact on Migration and Asylum - The Status Quo Problem. BRIDGE Network Working Paper 11, 2021.

Al-Kashef, Muhammad - Martin, Marie: EU-Egypt migration cooperation: at the expense of human rights. EuroMed Rights, 2019: available at: https://www.statewatch.org/media/documents/ news/2019/jul/Report-on-EU-Egypt-cooperation-on-migration\%20.pdf ( $5^{\text {th }}$ March 2021).

Bauerová, Helena (2018): Migration Policy of the V4 in the Context of Migration Crisis. Politics in Central Europe 14(2): 99-119.

Bauerová, Helena (2018): The V4 and European Integration. Politics in Central Europe 14(2): 121-139.

Burnay, Matthieu - Denecker, Matthias - Raube, Kolja - Hauck, Volker: Does the EU have the right instruments to finance assistance in protracted crises and the needs of upper middle income countries? European Parliament, 2016.

Cappelletti, Mauro -Seccombe, Monica - Weiler, Joseph, eds. (1986): Integration Through Law: Europe and the American Federal Experience. Vol. 1: Methods, Tools and Institutions De Gruyter.

Cassarino, Jean-Pierre (2010): Readmission Policy in the European Union, European Parliament.

Chmiel, Oskar J. (2018): The engagement of Visegrad countries in EU-Africa relations, Deutsches Institut für Entwicklungspolitik. Discussion Paper No. 24/2018: available at: http://dx.doi. org/10.23661/dp24.2018 (5 $5^{\text {th }}$ March 2021).

Circolo, Andrea - Hamulák, Ondrej - Lysina, Peter (2018): The Principle of Solidarity between Voluntary Commitment and Legal Constraint: Comments on the Judgment of the Court of Justice of the European Union in Joined Cases C-643/15 and C-647/15. Czech Yearbook of Public \& Private International Law 9: 155-173.

Colombeau, Sara Casella (2019): Crisis of Schengen? The effect of two 'migrant crises' (2011 and 2015) on the free movement of people at an internal Schengen border. Journal of Ethnic and Migration Studies 42(5): 625-641.

De Bruycker, Philippe - De Somer, Marie - De Brouwer, Jean-Louis, eds. (2019): From Tampere 20 to Tampere 2.0: Towards a new European consensus on migration. European Policy Centre.

Drinóczi, Tímea - Mohay, Ágoston (2018): Has the Migration Crisis Challenged the Concept of the Protection of the Human Rights of Migrants? The Case of Ilias and Ahmed v. Hungary, in Elżbieta, Kużelewska; Amy, Weatherburn; Dariusz, Kloza, eds., Irregular Migration as a Challenge for Democracy, Intersentia, pp. 97-112.

Duszczyk, Maciej - Podgórska, Karolina - Dominika Pszczółkowska (2019): From mandatory to voluntary. Impact of V4 on the EU relocation scheme. European Politics and Society 21(4): 470-487.

European Council of Refugees and Exiles (2020): Joint Statement: The Pact on Migration and Asylum: to provide a fresh start and avoid past mistakes, risky elements need to be addressed and positive aspects need to be expanded, 6 October 2020: available at: https://www.ecre. org/the-pact-on-migration-and-asylum-to-provide-a-fresh-start-and-avoid-past-mistakes-risky-elements-need-to-be-addressed-and-positive-aspects-need-to-be-expanded/ ( $5^{\text {th }}$ March 2021). 
Fischl, Vilmos (2019): The Role of the Ecumenical Council of the Churches in Hungary in Aiding Persecuted Christians, in Kaló, József -Petruska, Ferenc - Ujházi, Lóránd, Budapest Report on Christian Persecution, Háttér Kiadó, 259-272.

Global Detention Project (2018): Country Report - Immigration Detention in the Czech Republic: "We Will Not Accept Even One More Refugee", 2018: available at: https://www.globaldetentionproject.org/wp-content/uploads/2018/12/Immigration-Detention-in-the-Czech-Republic-December-2018-Web.pdf (5 $5^{\text {th }}$ March 2021).

Global Detention Project (2019): Country Report - Immigration Detention in Slovakia: Punitive Conditions Paid for by the Detainees. Global Detention Project, 2019: available at: https://reliefweb.int/sites/reliefweb.int/files/resources/Immigration-Detention-in-Slovakia-Online-.pdf.

Goldner Lang, Iris (2020): No Solidarity without Loyalty: Why Do Member States Violate EU Migration and Asylum Law and What Can Be Done? European Journal of Migration and Law 22(1): 39-59.

Goździak, Elżbieta M. - Main, Izabella (2020): Contesting Flexible Solidarity: Poland and the "Migration Crisis". Frontiers in Human Dynamics 2: 1-13.

Hautzinger, Zoltán (2019): Migratory Impacts on Law Enforcement, in Hautzinger, Zoltán, ed., Dynamics and Social Impact of Migration, Dialóg-Campus, pp. 149-172.

Karabegović, Dženeta (2020): Visegrad Countries and Migration Leadership Potential: Contextualizing Opportunities in light of the New Pact on Migration and Asylum and Beyond. Institute of International Relations Prague - Think Visegrad V4 Think-Tank Platform: available at:

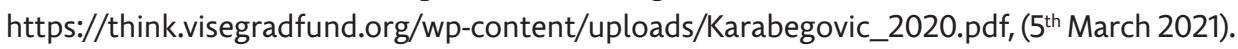

Krist, Niels (2020): Protecting the Formal Rule of Law in the EU's Asylum Policy: The CJEU's Judgment in C-757/17 (The Asylum Relocation Mechanism). BRIDGE Network Blog, 19 May 2020: available at: https://bridgenetwork.eu/2020/05/19/protecting-the-formal-rule-of-law-in-the-eus-asylum-policy-the-cjeus-judgment-in-c-757-17-the-asylum-relocation-mechanism (5 $5^{\text {th }}$ March 2021).

European Commission (2017): Relocation \& Resettlement: Sharing Responsibility within the EU and Opening Legal Pathways to Europe, European Union.

European Parliament (2016): Cost of non-Schengen: the impact of border controls within Schengen on the Single Market. European Union: available at: https://www.europarl.europa.eu/ RegData/etudes/STUD/2016/578974/IPOL_STU(2016)578974_EN.pdf.

European Parliament (2020): MEPs to grill Frontex director on agency's role inpushbacks of asylum-seekers. 30 th November 2020: available at: https://www.europarl.europa.eu/pdfs/ news/expert/2020/11/press_release/20201126IPR92509/20201126IPR92509_en.pdf (5 $5^{\text {th }}$ March 2021).

European Union Agency for Fundamental Rights (2020): Migration: Fundamental rights issues at land borders. European Union Agency for Fundamental Rights.

Glied, Viktor - Zamęcki, Łukasz (2021): Together, but still separated? Migration policy in the V4 countries. Politics in Central Europe 17(1S), 647-673. 
Gyeney, Laura - Molnár, Tamás (2016): Asylum Policy of the European Union, in Láncos, Petra Lea - Debisso, Kinga - Gyeney, Laura - Szabó, Marcel, eds., Union Policies, Eleven International Publishing, 183-249.

Karamanidou, Lena - Kasparek, Bernd (2018): Border Management and Migration Control in the European Union, RESPOND Research report D2. 1.

Kováts, András (2016): Migrációs helyzetkép Magyarországon, in Tarrósy, István - Glied, Viktor Vörös, Zoltán, eds., Migráció a 21. században, Publikon Kiadó, pp. 349-368.

Monar, Jörg (2010): The 'area of freedom, security and justice': 'Schengen' Europe, opt-outs, opt-ins and associates, in Dyson, Kenneth - Sepros, Angelos, eds., Which Europe? The politics of differentiated integration, Palgrave Macmillan, pp. 279-292.

Karageorgiou, Eleni (2020): The New Pact on Migration and Asylum: Why Pragmatism Cannot Engender Solidarity. Nordic Journal of European Law, 3(2): III-VIII.

Nagy, Boldizsár (2016): Hungarian Asylum Law and Policy in 2015-2016: Securitization Instead of Loyal Cooperation. German Law Journal 17(6): 1033-1082.

Nagy, Boldizsár (2017): Renegade in the Club - Hungary's Resistance to EU Efforts in the Asylum Field. Osteuropa Recht 63(4): 413-427.

Nagy, Boldizsár (2020): A pyrrhic? Victory concerning detention in transit zones and procedural rights: FMS \& FMZ and the legislation adopted by Hungary in its wake. EU Immigration and Asylum Law and Policy, 15 $5^{\text {th }}$ June 2020: available at: https://eumigrationlawblog.eu/a-pyrrhic-victory-concerning-detention-in-transit-zones-and-procedural-rights-fms-fmz-and-the-legislation-adopted-by-hungary-in-its-wake/ ( $5^{\text {th }}$ March 2021).

Nyzio, Arkadiusz (2017): The Second Revival? The Visegrád Group and the European Migrant Crisis in 2015-2017. Politeja 50(5): 47-98.

Pachocka, Marta (2016): Understanding the Visegrad Group States' Response to the Migrant and Refugee Crises 2014+ in the European Union. Yearbook of Polish European Studies 19: 101-132.

Pap, Norbert - Glied, Viktor - Reményi, Péter (2018): Two Faces of the Migration Crisis in Hungary, in Maria, Paradiso, ed., Mediterranean Mobilities: Europe's Changing Relationships, Springer International Publishing, pp. 55-64.

Pollet, Kris (2019) All in vain? The fate of EP positions on asylum reform after the European elections. EU Immigration and Asylum Law and Policy, 23 $3^{\text {rd }}$ May 2019: available at: http:// eumigrationlawblog.eu/all-in-vain-the-faith-of-ep-positions-on-asylum-reform-after-the-european-elections/ (5 $5^{\text {th }}$ March 2021).

Peers, Steve (2015): Relocation of Asylum-Seekers in the EU: Law and Policy. EU Law Analysis, 24 ${ }^{\text {th }}$ September 2015: available at: https://eulawanalysis.blogspot.com/2015/09/relocation-of-asylum-seekers-in-eu-law.html (5 $5^{\text {th }}$ March 2021).

Profant, Tomáš (2018): The Social Construction of Slovakia as a Donor and its Power Effects. Europe-Asia Studies 70(3): 365-387.

Remek, Éva (2015): A V4 kül-és biztonságpolitikája, in Rajnai, Zoltán - Beatrix Fregan - Kuna Zsuzsanna Marosné - Judit Ozsváth, eds., Tanulmánykötet a 6. Báthory-Brassai Nemzetközi Konferencia Előadásaiból, Óbudai Egyetem Biztonságtudományi Doktori iskola, pp. 1-2, 285-293. 
Rijpma, Jorrit (2016): The proposal for a European Border and Coast Guard: evolution or revolution in external border management? European Union.

Schütze, Robert (2015): EU Competences: Existence and Exercise, in Arnull, Anthony - Chalmers, Damien, eds., The Oxford Handbook of European Union Law, Oxford University Press, pp. 75-102.

Shaw, Malcolm N. (2017): International Law. Eighth Edition, Cambridge University Press.

Stepper, Péter (2018): A kényszermigráció mint biztonsági kihívás Közép-Európában: Eltérő percepciók, közös álláspont a visegrádi országokban. Budapesti Corvinus Egyetem.

Sundberg Diez, Olivia - Trauner, Florian (2021): EU return sponsorships: High stakes, low gains. European Policy Centre.

Szalai, Máté - Csornai, Zsuzsanna - Garai, Nikolett (2017): V4 Migration Policy: Conflicting Narratives and Interpretative Framework. CIDOB Colección Monografías.

Szczerbiak, Aleks (2017): How is the European migration crisis affecting Polish politics. EUROPP: European Politics and Policy. $6^{\text {th }}$ July 2017: available at: https://blogs.lse.ac.uk/europpblog/2017/07/06/european-migration-crisis-affecting-polish-politics/ ( $5^{\text {th }}$ March 2021).

Tarrósy, István - Vörös, Zoltán (2020): Hungary's Pragmatic Foreign Policy in a Post-American World. Politics in Central Europe, 16(1): 113-134.

Tóth, Norbert (2020): Tranzitzóna után, újabb jogi kihívások előtt? Horizont 2020/9, Migárciókutató Intézet: available at: https://www.migraciokutato.hu/wp-content/uploads/2020/05/20200529_HORIZONT_9_toth_norbert_tranzitzona_ut\%C3\%A1n_ujabb_ jogi_kihivasok_elott_elemzes.pdf (5 $5^{\text {th }}$ March 2021).

Vékony, Dániel (2021): Country Report Hungary, October 2019. GREASE - Religion, Diversity and Radicalisation: available at: http://grease.eui.eu/wp-content/uploads/sites/8/2019/10/ WP2-Mapping_Hungary-report_Daniel-Vekony-tcm².pdf (5 $5^{\text {th }}$ March 2021)

Weber, Bodo (2016): The European Refugee Crisis, the Balkan Route and the EU-Turkey Deal. Democratization Policy Council: available at: http://www.democratizationpolicy.org/pdf/ DPC_Policy_Paper_Europ_refugee_crisis_EU_Turkey_deal.pdf (5 th $^{\text {th }}$ March 2021).

Ágoston Mohay is associate professor and head of department at the Department of International and European Law of the Faculty of Law of the University of Pécs. His current research interests include the relationship between international law and EU law, EU migration and asylum law and the responsibility of international organisations. He is a member of the Hungarian branch of FIDE and - in his function as head of the Centre for European Education and Research of the Law Faculty a member of the European Migration Network.E-mail: mohay.agoston@ajk.pte.hu. 